Abditani : Jurnal Pengabdian Masyarakat 3 (1) 38-43

e-ISSN : 2622-4690

\title{
PKM KELOMPOK USAHA PENGOLAHAN PEPAYA DI DESA SIMORO KECAMATAN GUMBASA KABUPATEN SIGI PROVINSI SULAWESI TENGAH
}

\author{
Rukhayati $^{1^{*}}$ dan Awaludin ${ }^{1}$ \\ ${ }^{1}$ Program Studi Manajemen, Fakultas Ekonomi Universitas Muhammadiyah Palu \\ Jalan Hang Tuah No.114 Palu Sulawesi Tengah Indonesia \\ Email: rukhayatiumar@gmail.com
}

\begin{abstract}
ABSTRAK
Masyarakat desa Simoro memiliki potensi dalam mengembangkan usaha melalui pemanfaatan tanaman buah pepaya, hanya saja keterbatasan pengetahuan dan modal usaha yang menjadi kendala, oleh karena itu tujuan pelaksanaan kegiatan PKM yang dilaksanakan di Desa Simoro ini, untuk memberikan solusi atas permasalahan yang dihadapi oleh mitra melalui pelatihan dan keterampilan bagi kedua kelompok usaha wanita tersebut dalam mengolah tanaman buah pepaya menjadi produk olahan seperti kripik, selai pepaya dan gohu (asinan pepaya) yang merupakan salah satu kuliner masyarakat kota Palu. Sedangkan manajemen usaha diberikan kepada kedua kelompok usaha wanita seperti pemasaran produk hasil olahan, pengadministrasian kegiatan usaha kelompok untuk menciptakan kemandirian kelompok usaha, dan melakukan pendekatan secara terpadu agar dapat meningkatkan nilai ekonomis tanaman buah pepaya yang belum termanfaatkan secara optimal, menjadi produk olahan rumah tangga yang berkualitas. setelah mengikuti pelatihan peserta dapat memahami nilai jual dan manfaat dari bahan olahan pepaya, demikian juga pemahaman manajemen bagi kelompok usaha wanita yakni yang semula mereka tidak melakukan pencatatan atas biaya-biaya baik pemasukan atau pengeluaran, melalui pelatihan mereka memperoleh pengetahuan akan pentingnya melakukan pencatatan untuk mengetahui kondisi usaha yang mereka jalankan.
\end{abstract}

Katakunci : Kelompok usaha; pengolahan pepaya

\section{Pendahuluan}

Pepaya merupakan tanaman yang tumbuh subur di Desa Simoro dimana sebagian besar lahan ditanami pohon pepaya dan merupakan tanaman primadona yang sangat diharapkan dapat meningkatkan penghasilan masyarakat melalui olahan pepaya karena usaha pengolahan pepaya merupakan kegiatan yang sangat berpotensi untuk dikembangkan, terutama dalam mengisi peluang ekonomi yang terbuka lebar, dengan melalui pengolahnya maka nilai ekonomi pepaya tersebut dapat ditingkatkan, disamping itu semula pepaya dianggap tidak layak jual/ hanya untuk konsumsi langsung.

Kelompok usaha wanita Nosarara dan kelompok usaha wanita Lestari Indah, selama ini belum pernah memanfaatkan

tanaman buah pepaya sebagai bahan olahan, kedua kelompok ini hanya membuat bahan olahan dari pisang, ubi untuk diolah menjadi kripik, itupun dengan peralatan yang sederhana, kemudian dipasarkan dilingkungan desa simoro saja, berdasarkan informasi yang diperoleh dari ketua kelompok wanita Nosarara dan Lestari Indah, mereka belum pernah mengolah pepaya sebagai produk olahan karena minimnya informasi yang mereka peroleh, hanya sekedar pernah mendengar atau membaca bahwa pepaya dapat diolah menjadi kripik, selai dan gohu (asinan) yang merupakan salah satu kuliner masyarakat kota Palu, tidak adanya kegiatan sosialisasi ataupun pelatihan terkait dengan pemanfaatan buah pepaya, baik dari pemerintah maupun lembaga terkait baik 
lembaga pemerintah atau swasta, bagi kedua kelompok usaha wanita di desa simoro ini, keinginan untuk membuat kripik, selai pepaya dan gohu, telah ada hanya saja bagaimana cara membuatnya yang belum mereka ketahui ditambah lagi peralatan untuk membuat dua olahan pepaya tersebut pun tidak mereka miliki.

Adapun beberapa permasalahan utama yang dihadapi oleh kelompok usaha Nosarara dan Lestari Indah, adalah:

1. Buah pepaya sebagai tanaman yang tumbuh subur di Desa Simoro hanya dimanfaatkan sebagai makanan pelengkap saja dan dikonsumsi sebagai sayur untuk buah pepaya yang masih agak mengkal, jika pepaya dapat dimanfaatkan sebagai produk olahan tentu dapat mendatangkan keuntungan bagi kedua kelompok usaha dan tentu saja masyarakat sekitar desa Simoro umumnya.

2. Belum memperoleh pelatihan dalam pengolahan pepaya, mengingat pentingnya pengetahuan dan keterampilan dalam memanfaatkan pepaya sebagai produk olahan.

3. Tidak adanya peralatan yang akan digunakan untuk membuat olahan pepaya, bahkan selama ini dalam pembuatan kripik pisang atau ubi, peralatan yang digunakan oleh kedua kelompok terbilang sederhana.

4. Kelompok Nosarara dan Lestari Indah dalam memasarkan hasil usaha mereka selama ini hanya pada lingkungan desa Simoro saja, sehingga belum memenuhi standar prospek manajemen secara maksimal karena kemampuan menjaring bisnis masih lemah.

5. Belum adanya struktur organisasi yang jelas, hanya penunjukan saja untuk masing-masing ketua, sehingga menimbulkan tumpang tindih tugas dan tanggung jawab.
6. Perlunya pendampingan karena melihat kurangnya motivasi bisnis untuk pengembangan usaha, yang berakibat kegiatan usaha yang selama ini telah ada berjalan stagnan tanpa ada upaya untuk pengembangan skala usaha yang lebih besar.

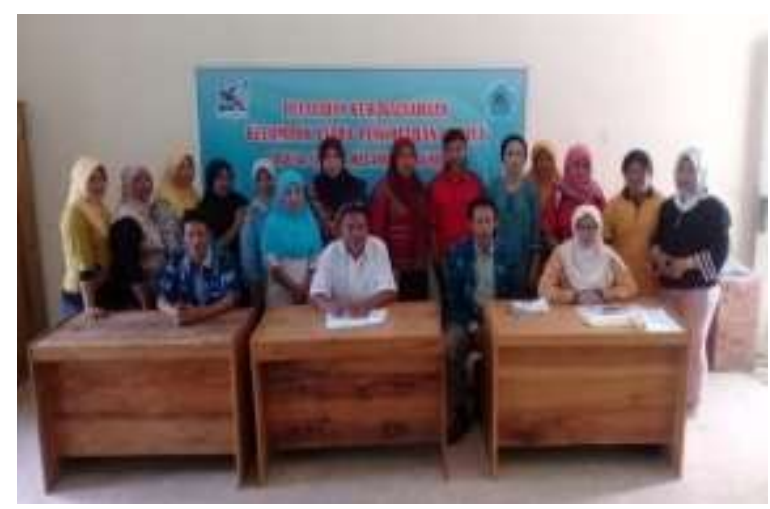

Gambar 1. Pelatihan Kewirausahaan

Target yang dicapai dalam kegiatan PKM di desa Simoro kecamatan Gumbasa ini agar dapat terukur, maka dijelaskan target kegiatan sebagai

berikut :

1. Memberikan informasi dan meningkatkan motivasi berwirausaha yang dapat menjadi industri rumah tangga yang berkualitas melalui tanaman buah pepaya yang banyak tumbuh di desa Simoro. Pelatihan dan praktek pembuatan kripik dan selai pepaya. Kedua kelompok usaha Nosarara dan Lestari Indah diminta untuk secara langsung mempraktekkan proses pembuatan olah makanan yang diperagakan hingga tuntas.

2. Penyediaan peralatan penunjang kegiatan yang sangat dibutuhkan misalnya kompor, penggoreng vakum sebagai alternatif pengganti kompor, wajan, sealer, alat pengering, tanpa tersedianya sarana dan prasarana penunjang, maka program ini tidak akan berjalan seperti yang diharapkan. 
Abditani : Jurnal Pengabdian Masyarakat 3 (1) 38-43

e-ISSN : 2622-4690

p-ISSN : 2622-4682

3. Pembinaan manajemen usaha baik Manajemen Produksi, Pengepakan, Distribusi, dan Pemasaran bagi kedua Kelompok usaha wanita Nosarara dan Lestari Indah.Terbentuknya produksi yang terstruktur dan terus menerus terhadap jenis usaha dan membuat trend baru olahan berbahan dasar pepaya yang diminati oleh masyarakat

4. Penciptaan struktur organisasi yang bisa memisahkan tugas dan tanggung jawab secara tegas antar masing-masing anggota organisasi, dan dapat mencerminkan sikap profesionalisme dengan menjalankan apa yang telah menjadi tugas dan tanggung jawab yang diberikan tanpa harus ada lagi saling memerintah satu sama lain sesama anggota kelompok.

5. Tetap melakukan pendampingan sebagai tindak lanjut kegiatan yang dilakukan secara berkala, dengan datang langsung ke desa Simoro maupun melalui media komunikasi telepon.

\section{Metode Pelaksanaan}

Solusi yang ditawarkan untuk mengatasi permasalahan yang terjadi dan terkait dengan target luaran yang telah ditetapkan adalah:

1. Persiapan kegiatan dilakukan untuk menyesuaikan produk olahan yang diminati peserta, waktu pelaksanaan dan tempat untuk melaksanakan kegiatan, sertapenyediaan sarana dan prasana untuk praktik. Peralatan praktik olahan buah pepayadan bahan praktik disediakan terlebih dahulu agar pelaksanaan pelatihan berjalanlancar dan efisien, seperti kompor, pisau, baskom, penggorengan danperalatan pendukung lainnya.

2. Sebelum diberikan pelatihan dan pendampingan pengolahan produk, masyarakat umumnya serta kedua anggota kelompok usaha wanita khususnya diberikan berbagai penyuluhan agar tujuan akhir dari pelaksanaan kegiatan ini bisatercapai. Pertama kali yang diberikan adalah memberikanpenyuluhan mengenai potensi tanaman buah pepaya yang tumbuh subur di desa mereka dan bisa menghasilkan berbagai olahan industri rumah tangga yang inovatif dan bercitarasa tinggi. Selain itu, diberikan pula penyuluhan mengenai kiat-kiat sukses menjadi seorang enterprenuer.

3. Setelah itu dilanjutkan dengan pelatihan dan pendampingan berbagai keterampilan. Tenaga ahli yang pernah mengikuti kegiatan pelatihan pembuatan produk olahan buah pepaya dengan dibantu oleh dua orang mahasiswa memberikan pelatihan dan pendampingan berupa pemanfaatan buah pepaya menjadi produk olahan. Diupayakan untuk menciptakan cita rasa yang lain dari yang lain agar bisa cepat merebut pangsa pasar, pelatihan dan praktik dengan materi olahan tanaman buah pepaya.

4. Penyuluhan mengenai manajemen operasional dan pemasaran hasil produk industri, pengelolaan usaha kecil, pengembangan pangsa pasar dan strategi untuk meningkatkan pendapatan juga menjadi prioritas. Penyuluhan ini diharapkan dapat menciptakan efektivitas kinerja untuk mencapai keuntungan kompetitif dengan biaya lebih rendah dan pelayanan lebih baik. Penyuluhan mengenai strategi pemasaran, diakhiri dengan diskusi untuk menyepakati strategi pemasaran pada usaha agar mempercepat pemasaran. Selanjutnya untuk memperluas jangkauan pasar, dibuka sistem keagenan baik secara offline maupun online bagi konsumen yang tertarik memasarkan produk. Strategi berikutnya adalah pemasaran dilakukan 
Abditani : Jurnal Pengabdian Masyarakat 3 (1) 38-43

e-ISSN : 2622-4690

secara langsung ke mini market, tokotoko, warung, sistem pengemasan yang sederhana, tetapi menarik minat konsumen untuk membeli produk tersebut karena konsumen merasa aman dan nyaman mengkonsumsi hasil produk.

5. Mengembangkan Membentuk pola kemitraan yang dikembangkan antara kelompok usaha Desa Simorodengan instansi terkait maupun mitra lain. Untuk menciptakan iklim usaha yang kondusif, bagiindustri kecil dan menengah maupun industri rumah tangga, pengembangan daya saing, sehingga diharapkan produk- produk sektor industri kecil mampubersaing di pasar global bisa mengenalkan produkproduknyakepada khalayak ramai, dan membuka peluang yang lebih besaruntuk mengembangkan usaha tersebut.

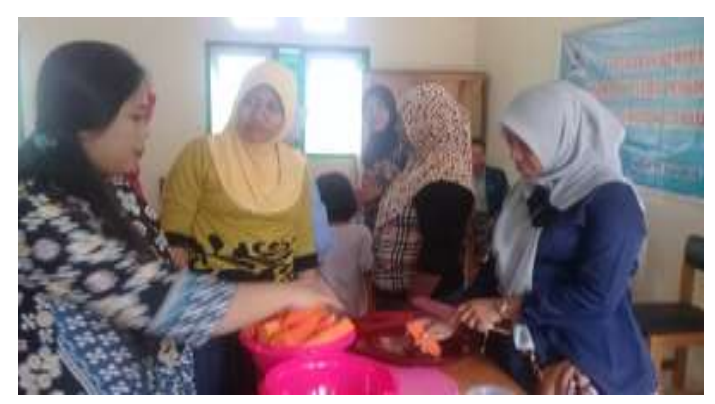

Gambar 2. Suasan pelatihan

Kegiatan pelatihan menggunakan Metode dengan cara pemberian materi melalui ceramah, kemudian dilanjutkan dengan praktik langsung oleh kedua kelompok usaha wanita Nosarara dan Lestari Indah. Cara ini dianggap efektif karena transfer pengetahuan yang diperoleh selama pelatihan akan lebih tersampaikan dengan baik jika peserta pelatihan itu sendiri yang menyampaikannya dan merasa bahwa

kegiatan pelatihan tersebut bermanfaat bagi mereka.

Evaluasi pelaksanaan program melalui pendampingan dan monitoring, untuk memahami bentuk pelatihan bagaimana meningkatkan hasil usaha, memantau dan mengukur kemajuan kegiatan yang telah dilaksanakan, dan mengumpulkan data-data yang diperlukan dalam proses evaluasi serta memberikan penilaian atas semua proses kegiatan setelah melakukan monitoring. Tujuan dari pelaksanaan evaluasi ini tentu saja untuk memantau pelaksanaan kegiatan kelompok usaha wanita Nosarara dan Lestari Indah terhadap hasil pelaksanaan kegiatan PKM.

\section{Hasil dan Pembahasan}

Sasaran dari program kegiatan program kemitraan masyarakat ini adalah ibu-ibu di Desa Simoro yang merupakan masyarakat yang secara ekonomis merupakan masyarakat biasa. Jumlah mitra ini ditetapkan dengan mempertimbangkan efisiensi dan intensitas pelaksanaan program.Mitra yang merupakan kelompok ibu-ibu rumah tangga yang berasal dari 2 kelompok yaitu Kelompok Wanita Nosarara dan Kelompok Wanita Lestari Indah Desa Simoro.

Adapun permasalahan yang ditangani dalam Program Kemitraan Masyarakat meliputi aspek manajemen penguatan kelompok, pengembangan usaha, dengan melatih ibu-ibu dari kelompok usaha wanita Nosarara dan Lestari Indahmembuat kripik, selai dan asinan dari daun buah pepaya. Pada hakekatnya, kegiatan Program Kemitraan masyarakatini solusi terhadap permasalahan yang dihadapi mitra melalui pendekatan secara terpadu, agar dapat meningkatkan nilai ekonomis pepaya yang masih belum termanfaatkan secara optimal. 

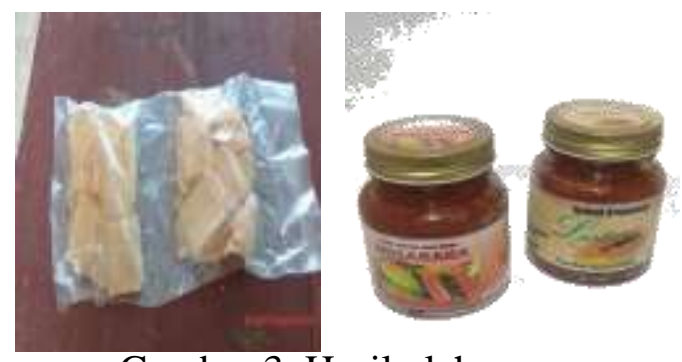

Gambar 3. Hasil olahan pepaya

Hasil yang diperoleh yakni adanya perubahan yang diharapkan setelah Program Kemitraan Masyarakat yakni dari segi keterampilan dalam mengolah buah pepaya menjadi produk olahan berupa kripik, selai dan asinan (gohu), yang sebelumnya kedua kelompok usaha wanita ini belum memiliki keterampilan pengolahan pepaya, setelah mengikuti kegiatan pelatihan kewirausahaan, kelompok ibu-ibu peserta pelatihan memiliki pengetahuan dan keterampilan mengolah pepaya menjadi kripik, selai dan asinan.

Semula pepaya di Desa Simoro oleh masyarakat hanya sebagai makanan pelengkap biasanya dibuat sayur, setelah mengikuti kegiatan pelatihan maka ibu-ibu dapat mengetahui bahwa pepaya dapat diolah menjadi produk yang dapat mendatangkan nilai jual, dari hasil pelatihan pun mereka memperoleh pengetahuan bahwa nilai jual pepaya menjadi lebih besar setelah diolah karena ada nilai tambah dari produk hasil olahan pepaya tersebut.

Luaran yang diharapkan adalah kemandirian masyarakat dalam mengelola olahan buah pepaya, masyarakat mampu meningkatkan kreativitasnya dalam pengembangan usaha, disamping itu produk hasil olahan dapat ditingkatkan nilai jualnya.

Terbinanya manajemen kelompok dimana masing-masing kelompok melakukan pencatatan keuangan dalam bentuk pembukuan sederhana dan diketahui oleh seluruh anggota kelompok, bertambahnya pengetahuan tentang kewirausahaan yang dapat memicu kreatifitas ibu-ibu dengan mengembangkan produk olahan lainnya.

\section{Kesimpulan}

Berikut ini kesimpulan yang dihasilkan adalah sebagai berikut :

1. Kegiatan pelatihan wirausaha bagi kelompok usaha wanita di Desa Simoro dapat meningkatkan motivasi kelompok dalam pengelolaan produk olahan pepaya.

2. Kegiatan pelatihan dan pendampingan Program Kemitraan masyarakat ini merupakan upaya peningkatkan pengetahuan dan keterampilan kelompok usaha dimana pada awalnya belum mengetahui bahwa pepaya dapat menjadi bahan olahan untuk kripik, selai dan asinan setelah mengikuti pelatihan peserta dapat memahami nilai jual dan manfaat dari bahan olahan pepaya, demikian juga pemahaman manajemen bagi kelompok usaha wanita yakni yang semula mereka tidak melakukan pencatatan atas biaya-biaya baik pemasukan atau pengeluaran, melalui pelatihan mereka memperoleh pengetahuan akan pentingnya melakukan pencatatan untuk mengetahui kondisi usaha yang mereka jalankan.

\section{Ucapan Terima Kasih}

1. Direktorat Riset dan Pengabdian Masyarakat Direktorat Jenderal Penguatan Riset dan Pengembangan Kementrian Riset, Teknologi, dan Pendidikan Tinggi yang telah mendanai pelaksanaan kegiatan Program Kemitraan Masyarakat ini.

2. Rektor Universitas Muhammadiyah Palu

3. Lembaga Penelitian dan Pengabdian Pada Masyarakat Universitas Muhammadiyah Palu

4. Bapak Dekan Fakultas Ekonomi Universitas Muhammadiyah Palu. 
Abditani : Jurnal Pengabdian Masyarakat 3 (1) 38-43

e-ISSN : 2622-4690

p-ISSN : 2622-4682

5. Bapak Herry Pampow, SE selaku kepala Desa Simoro yang telah mengizinkan dan memfasilitasi tim PKM selama pelaksanaan kegiatan.

\section{Daftar Pustaka}

Badan Pusat Statistik Indonesia. Statistik Impor Indonesia [Internet] 2012 [24 Februari 2012]. Tersedia di : http//www.bps.go.id.

Kalie, M.B. 2008. Bertanam Pepaya. Penebar Swadaya, Jakarta.

Kasmir, 2011, Kewirausahaan (Edisi Revisi), Rajagrafindo Persada, Jakarta

Suprapti, M.L. 2006. Aneka Olahan Pepaya Mentah dan Mengkal. Kanisius, Yogyakarta.
Suryana, Yuyus, Bayu Kartib, 2008, Kewirausahaan: Pendekatan Karakteristik Wirausahawan Sukses, Penada Media Grup, Jakarta

Suyanti, 2008, Pengaruh cara pengeringan dan lama penyimpanan terhadap daya terima manisan papaya Semangka Paris dan Bangkok. Jurnal Agritek . 2008; 17(11): 82-87 edisi khusus.

Yayang Ade Suprana, 2012, Pembuatan Keripik Pepaya Menggunakan Metode Penggorengan Vacuum Dengan Variabel Suhu dan Waktu, Tugas Akhir, Program Studi Diploma III Teknik Kimia Program Diploma Fakultas Teknik Universitas Diponegoro Semarang. 